\title{
INTEGRATING CORPORATE AND PERSONAL INCOME TAXES: THE CARTER COMMISSION PROPOSALS
}

\begin{abstract}
Grorge F. Break*
When Canada's Royal Commission on Taxation (the Carter Commission) made its now celebrated report to the government in Ottawa in early $1967,{ }^{1}$ an attractive avenue to tax reform, supremely simple at least in its logical consistency, was opened up. In a complex political and economic environment, however, tax rationality is far simpler to conceive than to deliver. Probably no aspect of the Carter Report (popularly named for the Commission's Chairman, the late Kenneth LeM. Carter) stirred up a greater hornets' nest than its advocacy of full integration of the corporate and personal income taxes, together with the adoption for the latter of a broad, comprehensive tax base of the Henry Simons type. ${ }^{2}$ Since that proposal, despite the shock and anger with which it was greeted in Canada, does offer a viable means of achieving a simplified structure for the income tax in the United States, it has been chosen for discussion in this paper.
\end{abstract}

I

The Corporate Profits Tax: Evaluation of Its Justifications

The case for changing to an integrated income tax must obviously begin with a hard look at the element which it would eliminate-that is, the separate corporate profits tax-and at the difference it would make. The corporate profits tax, though widely employed and hence politically respectable, suffers from an inherent weakness that bothers economists more than legislators-namely, its lack of theoretical justification. Expert discussion of this tax has centered around two schools of thought. One holds that the tax is justifiable on its own merits, presumably as a payment for corporate benefits received, and therefore has little relation to the personal income tax. The other maintains that the corporate tax is simply one element in the whole spectrum of ability-to-pay taxation and should be fitted into that universe as carefully as possible so as to avoid significant gaps or overlaps. The merits of these views cannot be exhaustively considered here, but a rapid summary of the arguments will provide a background for an evaluation of the Carter integration plan.

\footnotetext{
- Professor of Economics, University of California, Berkeley.

1 Report of the Royal Comomission on Taxation (1966).

'See Carter, Canadian Tax Reform and Henry Simons, II J. Law \& Econ. 23 (1968).
} 


\section{A. Payment for Benefits Received}

Adherents of the benefits principle as the basis for taxing corporations score an easy first round victory. Obviously corporations enjoy many kinds of government benefits. They depend upon local governments for police and fire protection, street construction and maintenance, even school services for their employees' children; the list could go on. Beyond that point, however, the arguments grow confused, for the problem is to relate these benefits in any direct way to corporate profits. In actual fact, the connection is either very loose or totally nonexistent. Government services of this kind clearly justify some general business levy, such as a local tax on value added, but they provide no support for a federal tax on corporate income. By the same token, the well known special privileges of incorporation, conferred in this country by state governments, may provide a strong argument for corporate taxation, but again the net profits tax is a questionable candidate. One of the most basic of these privileges, for example, is the limited liability of stockholders-a consideration far more important for shareholders of companies registering losses than for those of consistently profitable firms. More plausible is the argument that the corporate form permits the assembling of much larger stocks of capital, and hence presumably the earning of higher rates of profit, than would otherwise be possible. These grounds, however, would more clearly warrant a profits tax measured by incremental earnings-that is, profits over and above what could have been earned had the enterprise been organized as a partnership or sole proprietorship. The administrative impracticability of such a tax is obvious. No clearer a case can be made for the argument that the corporate tax is a "payment for social costs." Whatever diseconomies are generated by corporations are completely unrelated to their profits and are best handled by other types of taxes or by other types of government policy. All in all, it is hard indeed to establish a solid benefits-received justification for the federal corporate profits tax.

\section{B. Ability to Pay}

Argued on ability-to-pay grounds, the case for a separate, unintegrated corporate income tax also fares very badly, and this in spite of the fact that economists are still very uncertain about its incidence. In the event that the main burdens of this tax fall on corporate stockholders and other owners of capital, it places a disproportionate load on corporate source income and encourages an inefficient allocation of resources. If, on the other hand, the tax is significantly shifted either forward to consumers or backward to workers and landowners, its effects are bound to be haphazard and conducive to neither equity nor efficiency.

\section{Custom, Reliance, and the Federal Revenue}

Perhaps the most cogent argument in favor of retaining the corporate profits tax is that people have grown accustomed to it. As with any encumbrance that has been 
lived with for a sufficiently long period, the body politic has accomodated itself to it, and excision would involve some major post-operative adjustments. Musgrave, for example, has emphasized the importance of not making any alteration in the corporate profits tax that might impede the unshifting of any shifted burdens that currently rest on consumers or workers. ${ }^{3}$ Another problem is that stabilization policymakers have come to rely on their ability to use adjustments in this tax (via investment credits, tax rate changes, and so forth) as means of controlling shortterm fluctuations in corporate investment. Tax credits have also been looked upon with increasing favor of late as possible ways to encourage business to invest in ghetto areas, train disadvantaged workers, and engage in other socially desirable activities. Although alternative means of achieving these goals are certainly possible and are regarded by many as distinctly superior, ${ }^{4}$ tax credits do have their advocates, and the effectiveness with which credits could be applied to a fully integrated corporate income tax is certainly open to question.

Finally, elimination of the corporate profits tax per se would produce a very large drop in federal tax revenues, all of which would have to be made up elsewhere unless economic conditions at the time of the reform dictated a clear need for some fiscal stimulus. In this connection, it is interesting to note the Pechman-Okner estimates, derived from the Brookings-IRS Ig66 Federal Individual Income Tax File, that the entire Carter Commission package, including full corporate-personal income tax integration, could have been implemented in that year without loss of federal revenues and with lower personal tax rates in all brackets-the drop was from fourteen to $\mathrm{x} 2.8$ per cent at the bottom of the scale and from seventy to 53.I per cent at the top. ${ }^{5}$ At the same time, the federal income tax structure would have been made distinctly more progressive in its vertical incidence. Nevertheless, corporate tax integration would generate substantial benefits to corporate stockholders, most of whom are to be found in the higher income groups, and it is up to its advocates to design a tax reform package that would so counteract these distributional effects as to produce a net gain in aggregate tax equity.

\section{II}

\section{The Carter Integration Plan}

The significance of the Carter Commission's plan, which retains a tax on corporations but converts it into a withholding levy on both distributed and undistributed profits, can best be seen by comparing its effects with those of the current U.S. tax

\footnotetext{
${ }^{3}$ Musgrave, The Carter Commission Report, I Can. J. Econ. I59 (1968).

- See, e.g., Surrey, Tax Incentives-Conceptual Criteria for Identification and Comparison with Dircet Expenditures, paper presented at the Tax Institute of America Symposium on Tax Incentives, Nov, 2021, 1969; Surrey, Tax Incentives As a Device for Implementing Government Policy: A Comparison With Direct Government Expenditures, 83 HaRv. L. Rev. 705 (1970).

- Pechman \& Okner, Simulation of the Carter Commission Tax Proposals for the United States, 22 Nat'L TAX J. 2 (1969).
} 
law. Under our present, unintegrated system it can readily be demonstrated that the effective tax rate on distributed corporate source income is always higher than that on equal amounts of other kinds of income. ${ }^{6}$ This is so because distributed corporate income is taxed once at the corporate level and then again at full personal income tax rates when received as dividends (apart from the $\$$ roo dividend exclusion, which is important only to small stockholders). Undistributed corporate source income is also frequently taxed twice-once at the corporate level and then later in the form of realized capital gains on the relevant corporate shares-but the total effective tax rate is always lower than the rate on distributed corporate income, though it will be higher than their rates on noncorporate income for all shareholders in the lower and middle income brackets. These propositions are illustrated in the tabulation in Table $\mathrm{I}$, assuming a completely unintegrated corporate profits tax of fifty per cent and capital gains tax provisions effective in I969. The third column

TABLE I

Effective Tax Rates on Corporate and Noncorporate Source Income at Personal Tax Rate Levels of 20, 50, and 70 Per Cent

\begin{tabular}{c|c|c|c}
\hline \hline & \multicolumn{3}{|c}{ Corporate Source Income } \\
\cline { 2 - 4 } Noncorporate & & \multicolumn{2}{|c}{ Undistributed } \\
Source Income & Distributed & Current Realization & Indefinite Holding \\
\hline $20 \%$ & $60 \%$ & $55 \%$ & $50 \%$ \\
$50 \%$ & $75 \%$ & $621 \%$ & $50 \%$ \\
$70 \%$ & $85 \%$ & $62 \%$ & $50 \%$ \\
\hline
\end{tabular}

in the table requires a word of explanation. The tax rates shown there assume that after-tax retained corporate profits are reinvested at, or above, the corporation's current earning rate so that its share prices rise by the full amount of reinvested earnings per share. ${ }^{7}$ The investor is then assumed to realize these capital gains without delay so that they become subject to the long-term capital gains tax. The last column shows the opposite case of an investor who expects to hold his shares indefinitely and for whom, therefore, any future capital gains tax liability is too uncertain to have a significant present value. His total effective tax rate on undistributed corporate source income is consequently simply the corporate tax rate itself.

The Carter plan eliminates all of these complexities and inequities simply by ensuring that all corporate source income would be taxed currently at the same rates as equal amounts of noncorporate source income. The two key elements in the

\footnotetext{
${ }^{\circ}$ For a more detailed analysis of the tax rate relationships discussed in this paragraph, see Break, Integration of the Corporate and Personal Income Taxes, 22 NAT'L TAX J. 39 (1969).

${ }^{7}$ In any given year, of course, other factors may dominate the behavior of corporate stock prices. Over the long run, however, it does appear that common stock prices, on the average, rise by the amount of retained earnings per share or by a little more. Id. at 48 .
} 
proposal are a corporate withholding tax rate set equal to the top personal tax rate and a series of personal tax credits which precisely tailor the effective tax rate on corporate source income to the personal circumstances of each stockholder. Consider a shareholder who receives $\$ 100$ in dividends and whose share of retained corporate profits is also \$roo. Assuming that the latter amount was "allocated" to him in the Carter fashion, ${ }^{8}$ as corporations would have every incentive to do, and assuming a corporate withholding rate of fifty per cent, our shareholder would "gross-up" his dividend and allocated corporate income to \$200 in each case, include these amounts with his other taxable income, compute his total personal tax liability, and then deduct his two corporate tax credits of \$roo each, claiming a cash rebate from the government to the extent of any negative tax liability that resulted. As shown in Table 2, a shareholder in the twenty per cent tax bracket would have a "net" personal tax liability of $\$ \mathrm{I} 20$, resulting in a total tax of $\$ 80$ on $\$ 400$ of corporate source income and producing the correct effective tax rate of twenty per cent. A shareholder in the fifty per cent tax bracket would have no tax adjustment to make at the personal level since the amount withheld for him at the corporate level (\$200) would be exactly equal to his total tax liability on corporate source income. Since there would be no shareholders in higher tax brackets under the Carter plan, no one would be under-withheld and required to pay additional taxes on his personal tax return because of any corporate source income he happened to have. This feature of the plan would greatly improve the tax treatment of undistributed corporate source income. Clearly, it would provide a strong inducement for corporations to allocate retained earnings to their shareholders, since such action would not affect the net tax liability for recipients in the fifty per cent bracket and would result in tax reductions for all other recipients. Through this mechanism retained corporate profits would be taxed on a current basis, at the marginal tax rate appropriate for each individual stockholder. And, unlike the partnership method of integration to be discussed later, this scheme would create no liquidity problems for the individual shareholder. Since retained profit allocations would be added to the cost basis of each stockholder's shares for the purpose of computing his taxable capital gains, stock prices could rise by the full amount of retained earnings per share without creating additional personal tax liabilities. As I have discussed

\footnotetext{
${ }^{8}$ The amounts to be allocated from retained profits would be decided each year by the board of directors, and the results would be reported to the shareholders on a simple information slip similar to that shown here:
}

$\begin{array}{lcc} & \begin{array}{c}\text { Allocation } \\ \text { of Profits }\end{array} & \text { Dividend } \\ \text { 1. Report as income } & \$ 200 & \$ 200 \\ \text { 2. Claim as tax credit } & 100 & 100 \\ \text { 3. Change cost basis of shares } & 100 & 0 \\ \text { 4. Cash payment } & 0 & 100\end{array}$

Negative figures could be indicated by brackets, and separate forms for dividends and profit allocations would be unnecessary. 
TABLE 2

Tax Treatment of Corporate Source Income Under the Carter Plan

Before-tax Amount of Income

Tax Withheld at Corporate Level (50\% rate)

Dividends Plus Undistributed Profit Allocations

Grossed-up Dividends and Allocations

Total Personal Tax Liability

Tax Credit Entitlement

Net Personal Tax Liability

elsewhere, this should make a major contribution to the solution of the well-known "lock-in" problem associated with the taxation of capital gains on a realization basis."

Compared to present law, the Carter plan would add some complications to the corporate tax picture. Boards of directors would have to decide on the amounts of retained earnings to be allocated to their shareholders each year, and reports, no more complicated than our existing information returns for dividends, would have to be mailed in time for the shareholders to file their final income tax returns for the year in question. By themselves, these new features of the tax law do not appear to be particularly burdensome, and many would regard their cost as far outweighed by the improvements in tax equity they would bring about. Even more more important for present purposes, however, is the sound basis they would lay for future tax simplification. It has long been recognized that one of the most complex, and difficult to handle, features of present tax law is the shifting boundary between ordinary income and capital gains and losses. So long as the latter are taxed more lightly than the former, the government will have to guard that boundary with vigilance, and in the process create much socially-useless employment for tax lawyers and accountants, to say nothing of the diversion of high-priced taxpayer talents from productive activities to the refinement of complex taxminimization schemes. So long as a separate, unintegrated corporate profits tax exists in this country, however, there is no case for the full taxation of corporate capital gains and losses, and so long as these are lightly taxed it may be politically impossible to adopt full taxation of noncorporate capital gains. As will be seen in the next section, however, Canada may provide us with some valuable evidence on this score during the next few years.

A final comment on the Carter integration plan concerns its international aspects. In a world of unintegrated corporate taxes, no one country is likely to be anxious to adopt reforms that would reduce the income taxes it collects from foreign investors significantly below the levels collected by other countries. On this score, for example, a corporate credit for dividends paid, which is one of the frequently discussed methods of corporate-personal tax integration, would be relatively un-

\footnotetext{
${ }^{\circ}$ Break, supra note 6.
} 
attractive. By converting the corporate tax into one on undistributed profits alone, it would rationalize the tax treatment of distributed corporate source income, but in the process it would shift the taxation of that income from the country of origin (where it now mainly rests) to the country of residence. Given its high proportion of foreign corporate ownership, Canada would obviously be particularly sensitive to such considerations; the Carter plan neatly solved the problem by pro. viding the fifty per cent corporate tax would be a true tax for all foreign investors but only a withholding levy for Canadian shareholders. In the process, the Commission also considerably reduced the potential revenue loss from full corporate income tax integration, a problem that could not be so easily handled in the United States.

On grounds of both tax equity and tax simplicity, then, there is much to be said for full corporate-personal tax integration of the Carter type..$^{10}$ Nevertheless, the plan would represent a radical change from present taxing practices, and it may, therefore, prove too strong a fiscal medicine for most voters to swallow. Such, at least, appears to be the view of the Canadian government which, after studying the Carter Report and weighing the public discussion and complaints it had stimulated, issued its own White Paper on tax reform in late $1969 .{ }^{11}$ After suitable public debate, and perhaps some changes, most of the proposals contained in this White Paper will presumably be enacted into Canadian tax law. Those dealing with corporate tax integration and capital gains taxation are discussed in the next section.

III

\section{The Benson rg6g Tax Reform Proposals}

As outlined by Minister of Finance E. J. Benson, the Canadian government's program would tax capital gains more fully than they are now taxed in the United States, provide for full integration of the corporate and personal income taxes on an optional basis for closely-held corporations (by rules not unlike our provisions governing Subchapter $\mathrm{S}$ corporations), and take a partial step toward the integration of income taxes for widely-held corporations. Even at first glance it is obvious that any sharp tax distinction between widely-held and closely-held corporations is likely to complicate, rather than simplify, the tax law. Nevertheless, the distinction does have a good deal of economic rationale to support it, and its implementation may well turn out to be worth the cost.

In its economic characteristics the typical closely-held corporation is virtually identical to the partnership or sole proprietorship, and many tax experts have consequently proposed the so-called "partnership method of tax integration" for such corporations. It is this tradition that the Benson proposals follow. Upon elect-

\footnotetext{
${ }^{10}$ See id. for an analysis of the economic effects of integration.

${ }^{11}$ Canadian Ministry of Finance, Proposals for Tax Reform (1969).
} 
ing the option, the shareholders of any closely-held corporation would be taxed on their pro rata shares of total corporate profits, whether distributed to them or not, and there would be no separate corporate income tax. Full integration would thereby be achieved, but since a minority shareholder in a corporation that distributed no earnings might be placed in a financial squeeze by such tax treatment, provision is made that such elections must be unanimous. The extent to which the partnership method of tax integration would be adopted in practice, therefore, remains an open question. Where no such election is made, the closely-held corporation is to be subject to a flat withholding tax rate of fifty per cent, and shareholders may then gross-up both their cash and their stock dividends and take credit on their personal tax returns for the fifty per cent corporate tax attributable to such dividends. The full Carter integration plan would apply, therefore, to any nonelecting, closelyheld corporation that distributed all of its earnings as cash or stock dividends. ${ }^{12}$ It does not appear, however, that stock dividends will be as flexible an instrument for passing through tax credits to shareholders as would be the Carter-type retainedprofits allocations. The latter can be made in any amount whatsoever and reported on simple sheets of paper; the former are usually issued only in integral units and are reported on suitably engraved certificates. How important a barrier to full integration these differences may constitute for private Canadian corporations under the Benson plan remains to be seen.

Rejection of full Carter integration for widely-held corporations (which are also to be subject to a flat fifty per cent tax rate) is apparently based on the Canadian government's belief that "some level of corporation tax is passed on [by such corporations] to customers in the price which the corporations charge for their goods and services."13 Coming down squarely in the middle of this difficult issue, the White Paper proposes that Canadian shareholders be allowed to credit one-half of the fifty per cent corporate profits tax, when computing their personal taxes on cash and stock dividends, and be required to report for tax purposes one-half of any capital gains realized on the sale of shares of widely-held, public corporations. As far as distributed corporate source income is concerned, this would mean both fewer and smaller tax rebates-and larger, more frequent additional personal tax assessments-for Canadian stockholders than under the Carter plan. These effects are illustrated in Table 3 .

The Benson incentives for the declaration of stock dividends would clearly be less strong than the Carter incentives for the allocation of retained profits to Canadian stockholders. As a result, more corporate capital gains would be expected to accrue on the shares of public companies, other things equal, under the Benson plan. However, the potential lock-in effects thereby created are neatly countered by the White Paper's proposal that "individual taxpayers would revalue their holdings

\footnotetext{
12 The distribution would have to be made within $2 \frac{1}{2}$ years from the end of the taxation year in which the profits were earned. Id. at 49 .

${ }^{13} \mathrm{Id}$. at 50.
} 
TABLE 3

Tax Treatment of Distributed Corporate Income Under the Benson and Carter Plans

\begin{tabular}{ll|r|r|r}
\hline \hline & & \multicolumn{2}{|c}{ Marginal Tax Rate of Shareholder } \\
\cline { 3 - 5 } & & $20 \%$ & $50 \%$ & $70 \%$ \\
\hline Amount of dividend received & & $\$ 100$ & $\$ 100$ & $\$ 100$ \\
+ Allowable tax credit & (Benson) & 50 & 50 & 50 \\
& (Carter) & 100 & 100 & 100 \\
T Taxable dividend & (Benson) & 150 & 150 & 150 \\
Gross personal tax due & (Carter) & 200 & 200 & 200 \\
- Allowable tax credit & (Benson) & 30 & 75 & 105 \\
= Net personal tax due & (Carter) & 40 & 100 & 140 \\
& (see above) & & & \\
& (Benson) & -20 & 25 & 55 \\
& (Carter) & -60 & 0 & 40 \\
\hline
\end{tabular}

of shares of widely-held Canadian corporations in each year in which they attain an age that is divisible by five. ... [T] he revaluation [is to] take place as of the end of the month in which the significant birthday ... takes place."14 One can readily foresee the heightened anticipation with which many Canadian shareholders could be expected to approach their decade, and semi-decade, anniversaries under this plan! Nonetheless, periodic asset valuations of this type are perfectly feasible for the owners of public corporations, the Benson plan seems well-designed to avoid any artificial market effects from concentrations of tax-induced selling, and the proposal would greatly improve both the equity and the economic efficiency of the Canadian income tax.

As far as undistributed corporate source income is concerned, the Benson plan would equate its tax treatment to that accorded dividends only for the fifty-per-cent bracket shareholder, whereas the Carter plan, of course, would create this equality for all shareholders. Table 4 shows the treatment of retained profits under the Benson plan. Comparing the bottom lines of the last two tabulations, one will note that under the Benson plan low-income shareholders would prefer dividends to capital gains, while high-income shareholders would do the reverse. The latter, however, would have their preferences for retained earnings steadily weakened as the top personal tax rates, currently ranging up to 82.4 per cent (and extending as high as 8r.9 per cent in the first year of the Benson plan), were uniformly reduced to a top of only $5^{1.2}$ per cent by the end of the fifth year of the plan's operation. ${ }^{15}$

For a country long accustomed to the traditional British distinction between capital gains and income, the Benson proposals for the former represent a bold move toward modern conceptions of the proper way to measure individual abilities to pay income tax. With the single exception of those accruing on the shares of

\footnotetext{
11 Id. at 4 I.

${ }^{15} I d$. at 25 .
} 
TABLE 4

Tax Treatment of Undistributed Corporate Income of Public Corporations Under the Benson Plan

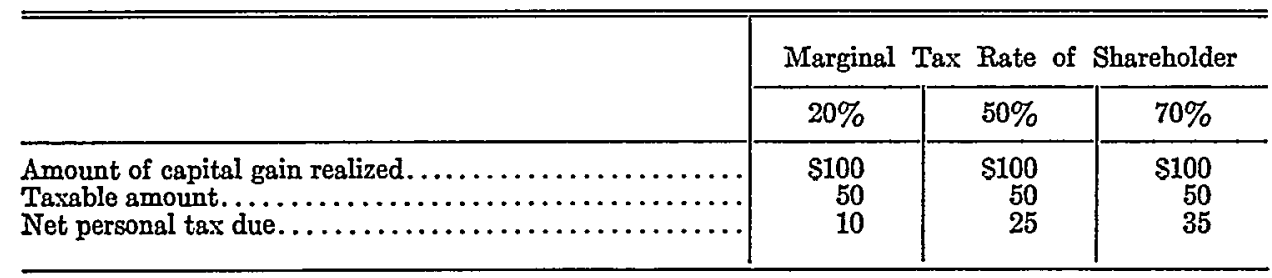

widely-held Canadian corporations, already discussed, all capital gains and losses are to be taxed at full income tax rates on a realization basis. As noted earlier, this appears to be one of those rare tax reforms that promise improvements in tax equity and tax simplicity at the same time.

\section{SUMMARY}

In the complex modern world tax equity and tax simplicity all too frequently point in opposite directions and present the harried tax policy-maker with nothing but a long series of difficult choices between irreconcilable alternatives. There is, however, one very important area of tax reform where this does not appear to be the case. Both corporate-source income and capital gains and losses are treated in very special and inequitable ways in the United States, and much unnecessary complexity appears to be added to the tax law as a result. Reporting to the Canadian government in early $196 \%$, the Carter Commission presented a novel plan for dealing with these problems-a plan which many tax experts regard as a model of logical purity and practical ingenuity. As outlined briefly above, the Carter plan would integrate the corporate and personal income taxes completely and tax capital gains and losses fully, many of them on a modified accrual basis. Not surprisingly, these proposals gave rise to a great deal of heated criticism and complaint. In spite of nearly three years of such critical evaluation, however, a large number of the Carter reforms in the corporate and capital gains areas have survived and appear in the recent official White Paper proposals for Canadian tax reform. There is still a good chance, it would appear, that some of the tax reforms most needed in the United States will be tried out first by our neighbor to the north. 